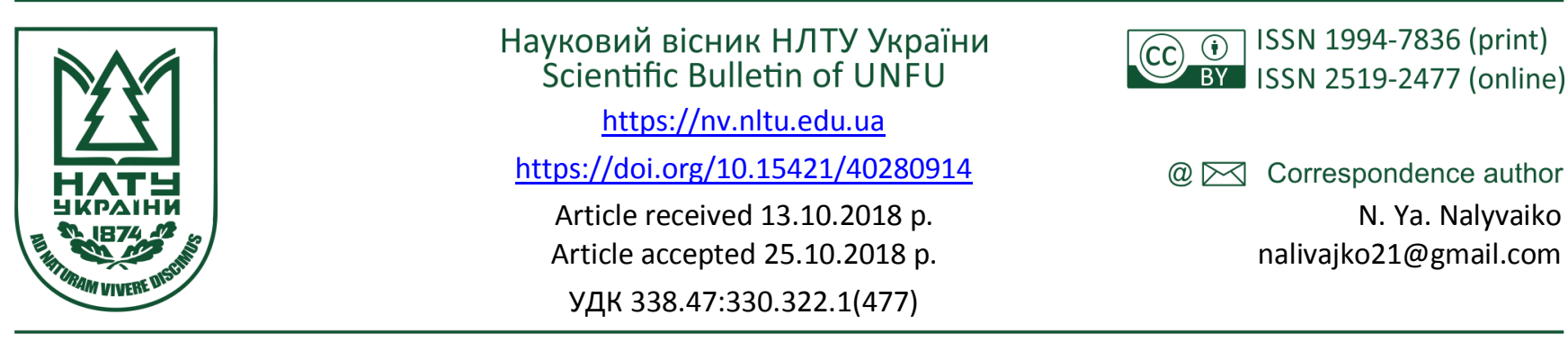

Н. Я. Наливайко, О. Г. Коломієць

Національний лісотехнічний університет Украйни, м. Львів, Украӥна

\title{
ПЕРСПЕКТИВИ РОЗВИТКУ ІТ-КЛАСТЕРІВ В УКРАЇНІ НА ОСНОВІ ВЕНЧУРНОГО ІНВЕСТУВАННЯ
}

Розглянуто та проаналізовано основні засади розвитку ІТ-кластерів як складової частини національної інноваційної екосистеми країни. Розроблено проблемно-цільову модель концептуалізації організаційно-економічних пріоритетів державного регулювання IT-кластерів у національній економіці, яка гармонізує суспільні та економічні інтереси учасників кластерного об'єднання та спрямована на формування державної кластерної політики на основі підвищення конкурентоспроможності ITсектору. Обгрунтовано практичні рекомендації щодо удосконалення державної політики розвитку IT-кластерів в Україні на основі венчурного інвестування. Удосконалено концептуальні основи дослідження розвитку інноваційних кластерів, а саме: наукових положень створення інноваційних кластерів як локалізованих економічних платформ у національній інноваційній системі, домінантних характеристик кластерної інтеграції, макроекономічних та мікроекономічних синергетичних ефектів та чинників процесу кластеризації. Встановлено, що незважаючи на позитивну динаміку венчурного інвестування в IT-сектор протягом останніх років, на жаль, воно й досі перебуває в процесі становлення. Оцінено інтенсивність впливу венчурного капіталу на становлення й розвиток IT-сектору в Україні. Досліджено основні фактори, котрі погіршують можливості розвитку цього виду інвестування в Україні. Проаналізовано структурні та регіональні особливості розвитку IT-кластерів. На основі проведеного аналізу виявлено, що розвиток ІТ-кластерів на основі венчурного інвестування $€$ перспективним і сучасним напрямом інвестування українських підприємств.

Ключові слова: інформаційні технології; ІТ-кластер; ІТ-сектор; венчурне інвестування; інноваційна екосистема країни.

Вступ. У сучасних умовах пріоритетності переходу до формування нової економіки, яка базується на знаннях та цінностях інформаційного суспільства, розвиток інформаційного простору та інформаційних технологій $\epsilon$ потужним чинником стимулювання економічного зростання, піднесення громадянського суспільства, підвищення рівня конкурентоспроможності національної економіки, суспільно-політичної та економічної інтеграції країни (Amosha, Salomatina \& Perederii, 2011). Прискорення процесу впровадження сучасних інформаційно-комунікаційних технологій у всіх сферах суспільного життя країни, розвиток електронної економіки та національної інформаційної інфраструктури, іiї інтеграція до світового інформаційного простору, поліпшення стану інформаційної безпеки є пріоритетними завданнями Національної програми інформатизації та Стратегії розвитку інформаційного суспільства в Україні.

Разом $з$ тим, впродовж останніх років триває тенденція до активізації процесів створення нових мережевих організаційних форм та кластерної взаємодії у сфері інформаційних технології на основі інтеграції зусиль ITпідприємств, науково-освітніх установ, державних структур, громадських організацій та інших учасників. Утворення кластерів у сфері інформаційних технології дає змогу не тільки оптимізувати управління економічними процесами під час створення, впровадження та використання інформаційних технологій, продуктів та послуг IT-підприємств, але й сформувати потужні інтегровані об'єднання 3 високим економічним потенціалом - як важливі суб'єкти розвитку національної економіки (Amosha, Salomatina \& Perederii, 2011).

Для стимулювання розвитку IT-кластерів на базі венчурного інвестування в Україні потрібні не тільки привабливі стартапи в IT-сфері, але й державна підтримка, що спрямована на сприятливе інституційне та економічне середовище для розвитку венчурного бізнесу в країні, активізації процесів залучення коштів венчурних інноваційних фондів. Відтак дослідження передумов і потенціалу розвитку IT-кластерів в Україні на основі венчурного інвестування сьогодні, безумовно, $\epsilon$ актуальним та своєчасним завданням (Andrushkiv, 2013; Asotsiatsiia, 2018).

Аналіз останніх публікацій. Різні аспекти вивчення науково-практичних проблем розвитку інноваційних кластерів, активізації процесів кластерної взаємодії в окремих видах економічної діяльності, і зокрема, в сфеpi інформаційних технологій, відображено в низці праць зарубіжних та українських дослідників, зокрема:

\section{Інформація про авторів:}

Наливайко Наталія Ярославівна, канд. екон. наук, доцент, кафедра економіки підприємства. Email: nalivajko21@gmail.com; https://orcid.org/0000-0003-4310-9367

Коломієць Олена Георгіївна, канд. екон. наук, інженер, кафедра економіки підприємства. Email: alenkolom@i.ua; https://orcid.org/0000-0002-0400-4805

Цитування за ДстУ: Наливайко Н. Я., Коломієць О. Г. Перспективи розвитку ІТ-кластерів в Україні на основі венчурного інвестування. Науковий вісник НЛтУ України. Серія Економічна. 2018, т. 28, № 9. С. 68-72

Citation APA: Nalyvaiko, N. Ya., \& Kolomiets, O. H. (2018). Prospects for the IT-clusters development in Ukraine based on venture investment. Scientific Bulletin of UNFU, 28(9), 68-72. https://doi.org/10.15421/40280914 
О. Амоші, Б. Андрушківа, Ю. Бажала, Є. Безвушко, М. Войнаренка, В. Геєця, О. Гудзя, П. Друкера, Я. Жаліло, Г. Іцковіча, М. Кастельса, Л. Калініченка, Б. Кваснюка, Ч. Кетельса, Г. Клейнера, О. Кузьміна, Д. Лук'яненка, Б. Мільнера, А. Мокія, Н. Мікули, В. Новицького, Ю. Павленка, А. Пилипенка, С. Розенфельда, В. Сизоненка, Е. Тоффлера, Л. Федулової, І. Ханіна, Й. Шумпетера, В. Чужикова, А. Юданова та ін.

Віддаючи належне зазначеному вище доробку науковців, зазначимо, що водночас потребують подальшого дослідження та розгляду питання вдосконалення механізмів державної політики розвитку IT-кластерів на основі венчурного інвестування (Andrushkiv, 2013; Asotsiatsiia, 2018).

Основні результати дослідження. У сучасних умовах глобальної конкуренції кластеризація $\epsilon$ ефективною формою внутрішньорегіональної, внутрішньонаціональної та міжнаціональної інтеграції, яка дає змогу забезпечити розвиток національної економіки на основі створення самостійних локалізованих гравців, які, зокрема, здатні конкурувати на міжнародній платформі (Voinarenko, 2014).

Макроекономічні синергетичні ефекти кластеризації полягають у підвищенні соціально-економічних показників розвитку країни (поліпшення торговельного балансу, підвищення рівня якості продукції, збільшення зайнятості та темпів інноваційного розвитку шляхом створення системи передачі нових знань і технологій); розвитку сектору малого та середнього підприємництва через створення нових інноваційних підприємств 3 високим рівнем спеціалізації в певних сферах економіки; підвищення рівня залучених венчурних інвестицій, інвестиційної привабливості та конкурентоспроможності кластерів, регіонів і країни загалом. Мікроекономічні ефекти визначають розширення сфери діяльності та ринків збуту продукції, підвищення частки інтелектуального продукту у валовій доданій вартості, нарощування стабільності й стійкості позицій на ринку, підвищення продуктивності завдяки доступу до висококваліфікованої робочої сили, інформації, технологічних знань, консалтингових послуг тощо.

Під час дослідження розвитку інноваційних кластерів визначено домінантні характеристики кластерної інтеграції, враховуючи географічний, синергетичний, iнтеграційний та мережевий підходи до взаємодії учасників, розуміння кластера як територіально-галузевого чи конкурентоспроможного об'єднання підприємницьких структур. Об'єднання в інноваційні кластери забезпечує дієвість та впорядкованість процесу концентрації різнопланових наукових і технологічних винаходів, формування стабільної системи поширення нових знань, технологій та інноваційного продукту в просторовій мережі взаємозв'язків. Саме формування системи постійних взаємовідносин між усіма учасниками кластера виступає каталізатором активізації обміну ідеями та передачі знань, трансформації винаходів в інновації, а інновацій - у конкурентні переваги (Pylypenko, 2008).

IT-кластер, як стратегічна міжорганізаційна мережа секторального (чи міжсекторального) характеру, об'єднує ресурси та провідні компетенції підприємств й організацій, що входять до його складу (зокрема, підприємства IT-сфери, державні та приватні інституції підтримки), а також формує специфічне культурне та соціальне середовище. Об'єднання підприємств IT-сек- тору на основі кластерної взаємодії створює додаткові вигоди в контексті: доступу та якості спеціалізованого сервісу в сфері інформаційних технологій; доступу до венчурних інвестиційних фондів; доступу до фахових і продуктивних людських ресурсів; передачі ринкової й технологічної інформації, знань і досвіду. Завдяки цьому, створюються конкурентні переваги, що призводить до зростання конкурентоспроможності як самого кластера, так і країни загалом (Hoshchynska, 2016; Kuzmin, et al., 2003).

IT-кластери, як елементи національної інноваційної екосистеми, створюють передумови для взаємодії іiі суб'єктів в організаційно-технічній, експертно-консультаційній, фінансово-економічній та інформаційній площині в процесі створення та реалізації інформаційних продуктів і послуг.

Розроблена проблемно-цільова модель концептуалізації організаційно-економічних пріоритетів державного регулювання IT-кластерів в національній економіці (рис. 1) гармонізує суспільні та економічні інтереси учасників кластерного об'єднання, і спрямована на: формування державної кластерної політики на основі підвищення конкурентоспроможності IT-сектору та комерціалізації IT-інновацій; державне регулювання кластерної взаємодії в ІТ-секторі на основі соціально-економічних пріоритетів розвитку країни; створення сприятливого організаційно-інституційного середовища розвитку IT-кластерів (Andrushkiv, 2013; Asotsiatsiia, 2018).

Основні нормативні акти українського законодавства в IT-сфері відповідають основним принципам та стратегічним пріоритетам глобального інформаційного розвитку, узгоджуються 3 правом Європейського Союзу. Проте рівень розбудови інформаційного суспільства в умовах євроінтеграційного курсу не відповідає потенціалу та можливостям України, що пов'язано 3 численними проблемами реального застосування чинного законодавства (неефективні процедури його реалізації, постійне недофінансування сфери, розпорошення управлінських функцій та бюджетних ресурсів), а також $з$ кризовими тенденціями соціально-економічного розвитку загалом (Zakon Ukrainy, 2015).

У сучасних умовах глобальної конкуренції система формування гармонізованого та сприятливого інституційного забезпечення розвитку IT-сектору повинна оперативно враховувати вплив інституційних (зокрема i неформальних), політичних, економічних, соціальних і глобальних чинників на ділову активність IT-компаній у процесі узгодження стратегічних пріоритетів підтримки розвитку сфери інформаційних технологій.

Незважаючи на позитивну динаміку венчурного інвестування в IT-сектор та успішні приклади розвитку IT-бізнесу України, як українська інноваційна екосистема, так і система венчурного інвестування досі перебувають у процесі становлення. Зокрема, аналітичні дослідження показали:

- головними суб'єктами індустрії венчурного інвестування в Україні виступають компанії з управління активами (КУА) та інститути спільного інвестування (ICI) закритого типу, які перебувають у їх управлінні. Незважаючи на негативну динаміку останніх чотирьох років, упродовж 2005-2015 pp. чисельність КУА виросла майже в 2 рази, а середньорічна динаміка зростання чисельності ICI становила 10,7\%. За цей період рівень концентрації управління активами ICI зростав в середньому на 10,3 \% щорічно; 
- відбувається зростання рівня концентрації індустрії на користь Києва та Київської обл., зокрема їх питома вага в загальній чисельності ICI за результатами 2015 р. становила $73,05 \%$

- за 10 років більш як у 2 рази зросла чисельність венчурних фондів, які становлять 87 \% ICI (на 30.06.2016 р.), з часткою активів 95,5\%;

- упродовж 2009-2015 pp. у структурі активів венчурних ICI частка цінних паперів скоротилась на $50 \%$ (від 70,2 до 20,2 \%), що пов'язано зі стагнацією фондового ринку України загалом (скорочення загальної кількості цінних паперів, допущених до торгів на фондових біржах, деактивація торгівлі ними);
- головними вкладниками в українські венчурні фонди залишалися вітчизняні інвестори - юридичні особи (понад 80 \% загальних вкладень), які за останні 7 років інвестували понад 710 млрд грн. Проте спостерігається тенденція до зростання розмірів вкладень та часток іноземних юридичних осіб та українських індивідуальних інвесторів;

- низькою $є$ присутність українських венчурних фондів із прозорими інвестиційними стратегіями та довгостроковими життєвими циклами, а в структурі венчурних інвестицій частка фінансування підприємств сфери високих технологій $є$ низькою через високу ризиковість проектів, порівняно зі сферою фінансових послуг та роздрібної торгівлі (Heitsia, et al., 2010; Statistical, 2018; Biuleten, 2013; Stratehiia, 2013).

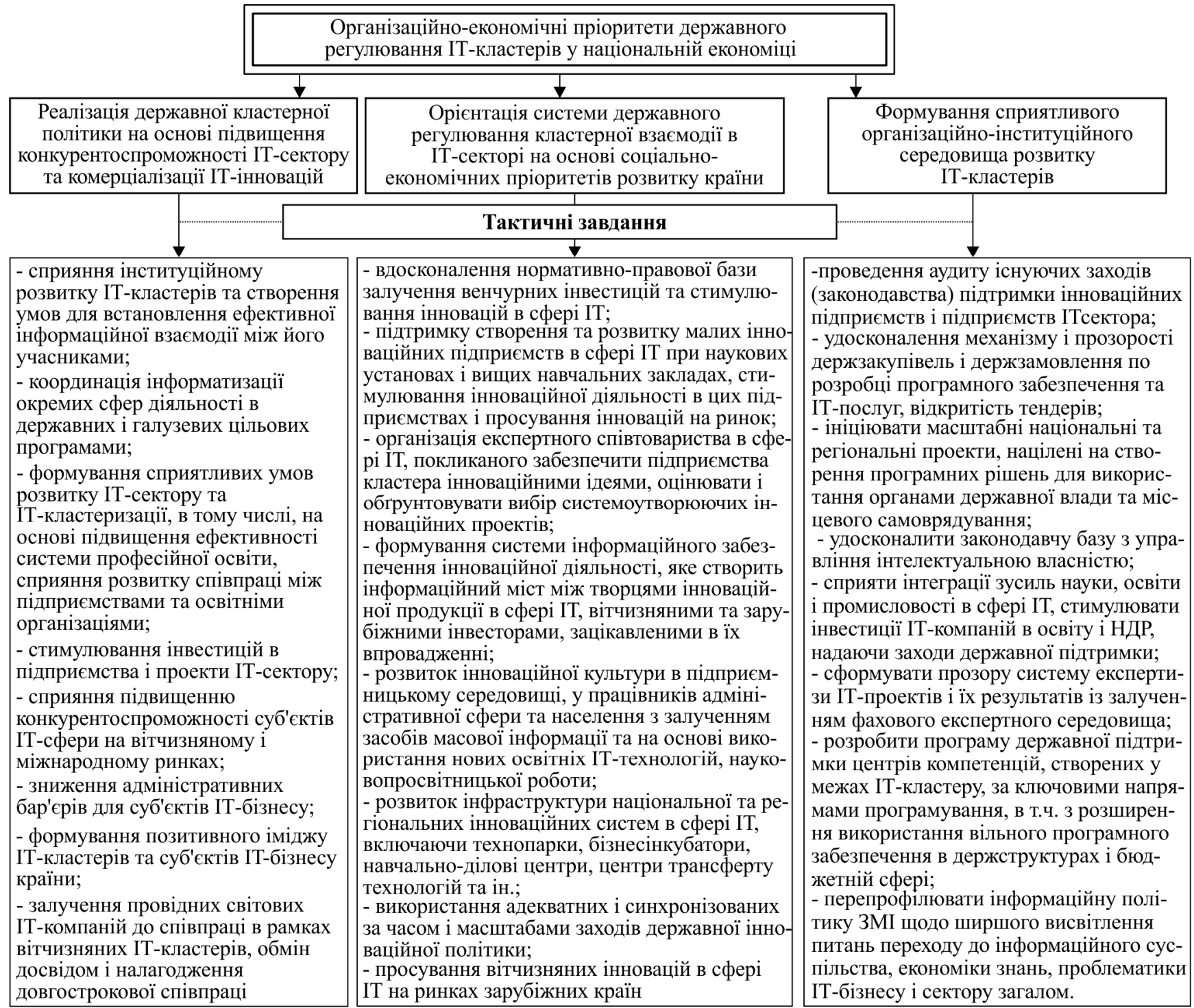

Рис. 1. Концептуалізація організаційно-економічних пріоритетів державного регулювання IT-кластерів у національній економіці (проблемно-цільовий підхід) (авторська розробка)

Україна, не володіючи розвиненою інноваційною інфраструктурою для створення та підтримки інновацій, продовжує залишатися економікою 3 низьким рівнем доданої вартості та конкурентоспроможності власної продукції через недостатні темпи розвитку високотехнологічних секторів. IT-сектор в Україні є один із сегментів інноваційної економіки, який найдинамічніше розвивається, зокрема і щодо експорту, та є одним із найважливіших джерел зростання міжнародної конкурентоспроможності України в найближчій перспективі.

Саме IT-проекти є найбільш затребуваними серед українських та закордонних інвесторів. Починаючи 3 2010 р., спостерігається значне пожвавлення венчурно- го інвестування в IT-сектор, який має свої фінансові (вищий рівень прибутковості) та податкові переваги, нижчі стартові суми коштів для розвитку IT-проекту від 10 тис. дол. США, тоді як в реальному секторі економіки - 0,5-1 млн дол. США.

Упродовж 2010-2015 pp. середньорічна динаміка росту IT-сектору становила $80 \%$, незважаючи на значний спад інвестиційної активності в 2014 р. (-55\%, або 49 млн дол. США порівняно 32013 р.). Найвищі темпи зростання IT-сектору України зафіксовано в 2012 та 2013 pp. - +150\% та $+47 \%$ відповідно, й особливо в 2015 р., коли загальний обсяг венчурних інвестицій 
стрімко зріс на 238 \% (або на 93 млн дол. США) порівняно з 2014 р. (рис. 2).

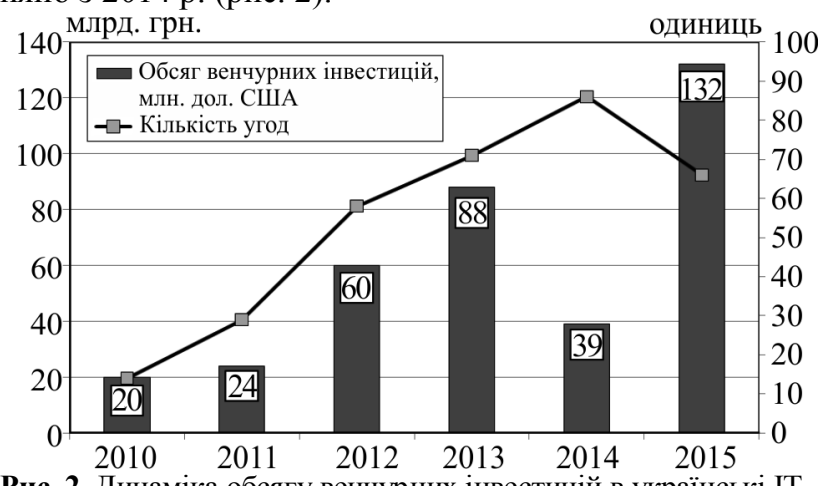

Pис. 2. Динаміка обсягу венчурних інвестицій в українські ITкоманії за 2010-2015 pp. (Heitsia, et al., 2010; Statistical, 2018; Biuleten, 2013)

Треба зауважити, що в структурі венчурних інвестицій за 2010-2015 рр. електронна комерція та програмне забезпечення $є$ провідними та найприбутковішими інтернет-сегментами (у 2015 р. їх сумарна частка становила 77 \%, або 109,3 млн дол. США). У структурі джерел фінансування нових та підтримки вже наявних ITпроектів в Україні середньорічна частка венчурного капіталу за аналізований період становила майже 60 \% від загального обсягу фінансування, а за 2015 р. його обсяг зріс більше ніж у 4 рази (від 3,2 до 13,8 млн дол. США).

Українським IT-компаніям у 2015 р. вдалося залучити 1,6 млн дол. США через краудфандинг, що в 4 рази більше за показник 2013 р. Більшість успішно проведених краудфандингових кампаній українських IT-підприємств представляють сегмент споживацького інтернету (consumer Internet) та інтернету речей (Internet of Things). Проблема у тому, що лише декілька венчурних фондів в Україні здатні підтримувати інноваційне чи технологічне підприємство впродовж повного циклу венчурного інвестування. Серед позитивних зрушень у контексті вдосконалення системи державного управління в Україні варто відзначити створення незалежної електронної системи державних закупівель ProZorro (економія бюджетних коштів за час свого функціонування майже 5,5 млрд грн), впровадження та розширення покриття послуг стандарту $3 \mathrm{G}$, системи електронного документообігу та окремих відкритих електронних державних реєстрів.

Треба звернути увагу, що одним із найбільш динамічних та провідних напрямів IT-сектору в Україні $\epsilon$ ITаутсорсинг (розроблення та продаж програмного забезпечення і надання IT-послуг), обсяг експорту продукції якого за 2015 р. охоплює 57,3 \% всього ринку сектора, впродовж 2003-2015 рр. зріс у 22 рази (від 110 млн до 2,51 млрд дол. США). Причому, конкурентні переваги України власне у великій кількості спеціалістів та високому рівні їх кваліфікації, одному з найнижчих рівнів оплати праці. Тому чотири українських IT-компанії (EPAM System, Intetics, Luxoft та Miratech) потрапили в міжнародний рейтинг 100 світових аутсорсерів. Послуги українських аутсорсингових IT-компаній є один із ключових напрямів національного експорту (4 місце в 2016 р.) 3 потенціалом виходу на провідну позицію в Україні до 2025 р., адже діяльність $90 \%$ IT-компаній зосереджена в напрямку надання якісних та надійних послуг на глобальному ринку. IT-послуги в 2015 р. ста- новили 43 \% від загального обсягу українського експорту послуг у США (Statistical, 2018; Biuleten, 2013).

Провідні аутсорсінгові IT-компанії стали ядром сформованих в Україні дев'яти ІТ-кластерів, які розміщені в Києві, Львові, Харкові, Одесі, Дніпрі, Луцьку, Івано-Франківську, Черкасах та Чернівцях.

Отже, привабливість країни для венчурного інвестування, як одного 3 основних компонентів інноваційної екосистеми країни, визначає потенційні можливості для активізації розвитку високоприбуткового сегменту ITсектору та внутрішнього ринку IT, і безпосередньо залежить від ділового клімату та стану бізнес-середовища країни, а також від рівня розвитку національної інноваційної екосистеми та ефективності ії функціонування.

Висновки. Підсумовуючи викладене вище, можна констатувати, що в сучасних умовах глобальної конкуренції та транснаціоналізації факторів економічного зростання, кластеризація $\epsilon$ ефективною формою внутрішньорегіональної, внутрішньонаціональної та міжнаціональної інтеграції (кооперування), котра дає змогу забезпечити розвиток національної економіки.

Зважаючи на високий потенціал кластерів у сфері інформаційних технології як ключових учасників розвитку національної економічної системи, розроблено проблемно-цільову модель концептуалізації організаційно-економічних пріоритетів державного регулювання IT-кластерів в економіці України, що сприятиме їх інституційному розвитку.

Незважаючи на позитивну динаміку венчурного інвестування в IT-сектор та успішні приклади розвитку IT-бізнесу, як українська інноваційна екосистема, так і система венчурного інвестування досі перебувають у процесі становлення. Низькою є присутність українських венчурних фондів із прозорими інвестиційними стратегіями та довгостроковими життєвими циклами, а в структурі венчурних інвестицій частка фінансового забезпечення інноваційних підприємств сфери високих технологій $є$ низькою через високу ризиковість проектів, порівняно зі сферою фінансових послуг та роздрібної торгівлі.

Політична та макроекономічна нестабільність, недосконала система захисту приватної та інтелектуальної власності, перешкоди для ведення міжнародної торгівлі та залучення іноземних інвестицій, непослідовна система регулювання істотно погіршують можливості для розвитку IT-сектору України та знижують його конкурентоспроможність.

\section{Перелік використаних джерел}

Amosha, O. I., Salomatina, L. M., \& Perederii, S. L. (2011). Analiz prychyn nyzkoi innovatsiinoi aktyvnosti vysokotekhnolohichnykh pidpryiemstv Ukrainy. Ekonomika promyslovosti, 4, 165-179. [In Ukrainian].

Andrushkiv, B. M. (2013). Vplyv ekonomichnoho potentsialu rehionu na rozvytok klasternykh obiednan pidpryiemstv. Ekonomichnyi prostir, 79, 46-54. Retrieved from: http://nbuv.gov.ua/UJRN/ecpros 201379 7. [In Ukrainian].

Asotsiatsiia. (2018). Ukrainska Asotsiatsiia Investytsiinoho Biznesu UAIB: Kvartalni ta richni ohliady rynku ISI v Ukraini. Retrieved from: http://www.uaib.com.ua/analituaib/publ ici quart.html. [In Ukrainian].

Biuleten. (2013). Ofitsiinyi sait Natsionalnoho Informatsiinoho Tsentru zi Spivrobitnytstva z YeS u sferi nauky i tekhnolohii. "IKT u ramkovii prohrami "Horyzont 2020". Biuleten № 1, Liutyi. Retrieved from: http://www.fp7-ncp.kiev.ua/index.php/uk/. [In Ukrainian]. 
Heitsia, V. M. (Ed.), et al. (2010). Novyi kurs: reformy v Ukraini 2010-2015. Natsionalna dopovid. Retrieved from: http://www.nbuv.gov.ua/books/2010/10nandop/index.html. [In Ukrainian].

Hoshchynska, D. Ya. (2016). Formuvannia komunikatsiinoi stratehii v umovakh klasternoi vzaiemodii pidpryiemstv. Stalyi rozvytok ekonomiky, 1(30), 110-115. [In Ukrainian].

Hrytsiuk, Yu. I., \& Andrushchakevych, O. T. (2018). Means for determining software quality by metric analysis methods. Scientific Bulletin of UNFU, 28(6), 159-171. https://doi.org/10.15421/40280631. [In Ukrainian].

Kuzmin, O. Ye. (Ed.), Kniaz, S. V., Tuvakova, N. V., \& Kuznietsova, A. Ya. (2003). Investytsiina ta innovatsiina diialnist: monohrafiia. Lviv: LBI NBU, 233 p. [In Ukrainian].
Pylypenko, A. A. (2008). Stratehichna intehratsiia pidpryiemstv: mekhanizm upravlinnia ta modeliuvannia rozvytku: monohrafiia. Kharkiv: VD "Inzhek", 408 p. [In Ukrainian].

Statistical. (2018). Ofitsiinyi sait European Statistical Office. Retrieved from: $\mathrm{http}: / / \mathrm{ec}$.europa.eu/eurostat. [In Ukrainian].

Stratehiia. (2013). Stratehiia rozvytku informatsiinoho suspilstva v Ukraini: Rozporiadzhennia Kabinetu Ministriv Ukrainy № 386-r vid 15 travnia 2013 r. Retrieved from: http://zakon5.rada.gov.ua/laws/show/ 386-2013-\%D1\%80. [In Ukrainian].

Voinarenko, M. P. (Ed.) (2014). Klastery v ekonomitsi Ukrainy: monohrafiia. Khmelnytskyi: KhNU, FOP Melnyk A. A., 1085 p. [In Ukrainian].

Zakon Ukrainy. (2015). Pro osnovni zasady rozvytku informatsiinoho suspilstva v Ukraini na 2007-2015 roky. Retrieved from: http://zakon5.rada.gov.ua/laws/show/537-16. [In Ukrainian].

Н. Я. Наливайко, А. Г. Коломиеч

Национальный лесотехнический университет Украины, г. Львов, Украина

\section{ПЕРСПЕКТИВЫ РАЗВИТИЯ ІТ-КЛАСТЕРОВ В УКРАИНЕ НА ОСНОВЕ ВЕНЧУРНОГО ИНВЕСТИРОВАНИЯ}

Рассмотрены и проанализированы основные принципы развития IT-кластеров как составляющей национальной инновационной экосистемы страны. Разработана проблемно-целевая модель концептуализации организационно-экономических государственного регулирования IT-кластеров в национальной экономике, которая гармонизирует общественные и экономические интересы участников кластерного объединения и направлена на формирование государственной кластерной политики на основе повышения конкурентоспособности IT-сектора. Обоснованы практические рекомендации по совершенствованию государственной политики развития IT-кластеров в Украине на основе венчурного инвестирования. Усовершенствованы концептуальные основы исследования развития инновационных кластеров, а именно: научных положений создания инновационных кластеров как локализованных экономических платформ в национальной инновационной системе, доминантных характеристик кластерной интеграции, макроэкономических и микроэкономических синергетических эффектов и факторов процесса кластеризации. Установлено, что несмотря на положительную динамику венчурного инвестирования в ITсектор в последние годы, к сожалению, оно до сих пор находится в процессе становления. Оценена интенсивность воздействия венчурного капитала на становление и развитие IT-сектора в Украине. Исследованы основные факторы, которые ухудшают возможности развития данного вида инвестирования в Украину. Проанализированы структурные и региональные особенности развития IT-кластеров. На основе проведенного анализа выявлено, что развитие IT-кластеров на основе венчурного инвестирования является перспективным и современным направлением инвестирования украинских предприятий.

Ключевые слова: информационные технологии; IT-кластер; IT-сектор; венчурное инвестирование; инновационная экосистема страны.

N. Ya. Nalyvaiko, O. H. Kolomiets

Ukrainian National Forestry University, Lviv, Ukraine

\section{PROSPECTS FOR THE IT-CLUSTERS DEVELOPMENT IN UKRAINE BASED ON VENTURE INVESTMENT}

The authors have considered the peculiarities of IT clusters development in Ukraine on the basis of venture investment. Scientific provisions of creation of innovative clusters creation as localized economic platforms in the national innovation system have been improved. Dominant characteristics of cluster integration, macroeconomic and microeconomic synergistic effects and the main factors of the process of clusterization have been established. In contrast to existing approaches, this allows systematical taking into account the functional, organizational, economic and spatial aspects of the implementation of the communication and integration potential of cluster formation. The dominant characteristics of cluster integration are defined. The benefits of combining enterprises from clusterization are presented. The problem-purpose model of conceptualization of organizational and economic priorities of state regulation of IT clusters in the national economy is developed. The institutional and economic principles of the formation of the state policy on the development of IT sphere in Ukraine are diagnosed. The basic normative acts of Ukraine's legislation in the IT sphere are identified to be agreed with the legislation of the European Union. Conducted analysis of IT business development in Ukraine has shown positive dynamics of the development of venture investing in the IT sector. Conducted analytical researches have shown that the main subjects of the industry of venture investing in Ukraine are asset management companies and closed-end joint investment institutions that are in their management. Domestic investors are revealed to remain the main contributors to Ukrainian venture funds today. The volume of venture investments in Ukrainian IT companies is presented. It was investigated that e-commerce and software occupy a significant share in the structure of venture investments. One of the leading IT sectors in Ukraine is found to be IT outsourcing. Nine largest IT clusters of our country are identified. On the basis of the conducted analysis, it has been established that clusterization is the effective form of integration, which enables ensuring the development of the national economy.

Keywords: information technology; IT cluster; IT sector; venture investment; country's innovation ecosystem. 